\title{
Prenatal Developmental Toxicity of Crocus sativus (saffron) in Wistar rats
}

\author{
Ramesh Edamula $^{1 *}$, M.Deecaraman ${ }^{2}$, D.P.Santhosh Kumar ${ }^{1}$, H.N.Krishnamurthy ${ }^{1}$, M.Latha ${ }^{1}$ \\ ${ }^{1}$ Department of Safety Assessment, Advinus Therapeutics Limited, Peenya II Phase, Bangalore - 560 058, India \\ ${ }^{2}$ Department of Biotechnology, Dr.M.G.R Educational and Research Institute, Maduravoyal, Chennai - 600 095, India \\ *Corresponding author E-mail: edamularamesh@gmail.com
}

\begin{abstract}
The prenatal developmental toxicity of Crocus sativus (saffron) was evaluated in a mammalian species taking Wistar rat as the model. Saffron administered as an oral gavage from Day 5 of gestation (day of implantation) until Day 19 of gestation at the doses of 50, 250 and $1000 \mathrm{mg} / \mathrm{kg} / \mathrm{day}$ did not elicit any effects on maternal body weight gains, food intake, gravid uterine weight, corpora lutea and implantation counts, pre and post implantation loss, litter size, weight and length. No abnormalities in the fetuses were noticed when subjected to external, soft tissue and skeletal examinations. The results obtained conclude that saffron did not induce maternal toxicity and structural and / or other abnormalities in the fetus and hence saffron is considered to have no teratogenic potential.
\end{abstract}

Keywords: Abnormalities, Fetus, Litter, Saffron, Skeletal.

\section{Introduction}

Crocus sativus is an herbaceous perennial cormous plant belonging to family Iridacea and is commonly known as saffron. Saffron contains more than 150 volatile and aroma yielding compounds The value of saffron is determined by the existence of three main metabolites - Crocin and its derivatives which are responsible for colour, Picrocrocin responsible for the bitter taste and Safranal responsible for the odour/aroma. The flower styles which are what basically form commercial saffron used by most people either for medicinal or culinary purposes. It has been reported that saffron has anti-inflammatory, antidiabetic, anticancer, hypolipaemic, anti-spasmodic or anti-seizure, expectorant effects. It is also a protective agent against chromosomal damage, a modulator of lipid peroxidation, for reducing blood pressure and also used in treatment of psoriasis (Bhargava 2011). In contrary to beneficial effect, information related to saffron toxicity has also appeared (HosseinZadeh et al. 2013). Crocetin, a carotenoid isolated from saffron has been found to be a teratogen (Martin et al. 2002). At low doses, saffron causes the stimulation of the pregnant uterus and in larger amounts can cause contraction and spasm leading to abortion and possible toxic symptoms. Although generally saffron is considered to be safe, it was decided to evaluate the effect of saffron on embryo fetal developmental toxicity (teratogenicity) potential to induce structural and /or other abnormalities in the fetuses when administered orally to pregnant rats during gestation days 5 through 19.

\section{Material and methods}

\subsection{Saffron}

Saffron (stigma of flower) was obtained from Indian Saffron Industry, Bagander, Pampore, Kashmir - 192121, India. The obtained material was authenticated by means of a spectrophotometric method based on International Organization for Standardization (ISO) 5453, Part II, 1996 at Central Food Technological Research Institute, Mysore-570020, India and a test report provided by the analyzer. The results indicated that the three main components present in the material on dry basis were: Picrocrocin -72.7 $\%$, Safranal $-51.6 \%$ and colouring strength $-142.5 \%$. No added artificial colour was present in the material.

\subsection{Animals and methodology}

Wistar rats, in-house bred at Department of Safety Assessment, Advinus Therapeutic Limited, Peenya Industrial Area, Bangalore - 560058, India were used in the experiment. 24 females confirmed mated by vaginal smear examination with weight ranging from 185 to 238 grams and 11 to 12 weeks old were divided into 4 groups of 6 each and housed in a barrier facility with standard laboratory condition of $12-15$ filtered fresh air changes, temperature range of 20 to $23{ }^{\circ} \mathrm{C}$, relative humidity of 30 to $70 \%$ with 12 hours fluorescent light and 12 hours dark cycle and with free access to food and water. The experimental project was approved by the Institutional Animal Ethics Committee (Proposal No. 023, dated 21 March, 2012).

6 animals in Group I received only the vehicle (Milli-Q water) at $10 \mathrm{~mL} / \mathrm{kg}$ body weight through oral gavage. The 6 animals each in Group II, Group III and Group IV received saffron suspended in Milli-Q water at the doses of $50 \mathrm{mg} / \mathrm{kg} / \mathrm{day}, 250 \mathrm{mg} / \mathrm{kg} / \mathrm{day}$ and $1000 \mathrm{mg} / \mathrm{kg} / \mathrm{day}$, respectively at $10 \mathrm{~mL} / \mathrm{kg}$ body weight through oral gavage. All the presumed pregnant females were continuously dosed from Day 5 of gestation (day of implantation) until Day 19 of gestation. Animals were weighed on specified intervals and food intake was also measured. Daily records of activity with reference to appearance and behavior were maintained. 
All the presumed pregnant females were euthanized under isoflurane anesthesia on Day 20 of gestation, blood collected for biochemical investigation using Roche/Hitachi 902 (Hitachi HighTechnologies Corporation, Tokyo, Japan) Automatic Analyzer and then the maternal viscera were examined macroscopically. The ovaries were removed and placed in a prelabelled container and the corpora lutea were counted immediately under a dissecting microscope. The gravid uterus was cut open along the antemesometrial side exposing the amniotic sacs. The sacs were ruptured and the number and position of implantation, early or late resorptions and dead or live fetuses were recorded. The umbilical cord of each fetus was cut and fetuses removed in a sequential order as present in the uterus, blotted dry and placed in a tray. The fetuses were then sexed, individually weighed and the crownrump length measured using a digital vernier caliper. External examination of fetuses for morphological abnormalities under an illuminated magnifying lens at a magnification of $5 \mathrm{X} / 10 \mathrm{X}$ was made. All the live fetuses are euthanized under isoflurane anesthesia. Following which $50 \%$ of fetuses are transferred into $70 \%$ ethyl alcohol for visceral/soft tissue evaluation under an illuminated magnifying lens at a magnification of 5X/10X (Staples 1974) and the remaining $50 \%$ fetuses are skinned, eviscerated and transferred into $70 \%$ ethyl alcohol for skeletal abnormalities (Staples \& Schnell 1964). The specimens for skeletal observations was processed and stained using alizarin red stain for the ossified parts and evaluated under a Stereoscopic Zoom microscope with typical magnification levels of $8 \mathrm{X}$ to $80 \mathrm{X}$.

\section{Statistical analysis}

Comparisons were made between the saffron exposure groups and the control using Dunnett's method following one way analysis of variance (ANOVA) for parameters related to maternal body weight, corrected maternal body weight, gravid uterine weight, food consumption, number of corpora lutea, number of implantations, litter size, litter weight and length and fetus number. The incidences of pre and post implantation loss, number of early and late resorptions were analyzed using Kruskal Wallis test. The percentages of skeletal malformations, sex ratio, dams with any resorptions were analyzed using $2 \mathrm{X} 2$ contingency table. A probability of 0.05 was accepted as statistically significant for all the applied tests.

\section{Experimental results}

\subsection{Mortality and clinical signs}

In general, no mortality or clinical signs of toxicity were found in the rodent dams throughout the treatment period except for the slight yellowish coloured feces at the highest dose of $1000 \mathrm{mg} / \mathrm{kg} / \mathrm{day}$ dose which are considered to be related to the colour of saffron which is administered and are non-adverse in nature. In addition, no gross abnormalities were detected in the dams at caesarean section.

\subsection{Fertility and maternal body weight gain during pregnancy}

Fertility Index, Gestation Index, Maternal body weights and body weight gains were unaffected by the administration of saffron in the three treated groups. The corrected body weight gains were also statistically similar with the control group (Table 1). The food intake was also statistically similar in the three treated groups compared with the control group.
Table 1: Fertility and Maternal Body Weight Gain

\begin{tabular}{|c|c|c|c|c|}
\hline \multirow[b]{2}{*}{ End Point } & \multicolumn{4}{|c|}{ Treatment } \\
\hline & Control & $50 \mathrm{mg} / \mathrm{kg} /$ day & $\begin{array}{l}250 \\
\mathrm{mg} / \mathrm{kg} / \text { day }\end{array}$ & $\begin{array}{l}1000 \\
\mathrm{mg} / \mathrm{kg} / \text { day }\end{array}$ \\
\hline No. of females & 6 & 6 & 6 & 6 \\
\hline Fertility Index ${ }^{a}$ & 100 & 100 & 100 & 100 \\
\hline $\begin{array}{l}\text { Gestation Index }{ }^{b} \\
\text { Maternal Body } \\
\text { Weight Gain } \\
\text { during Pregnancy } \\
(\mathrm{g})^{\mathrm{c}}\end{array}$ & 100 & 100 & 100 & 100 \\
\hline $\begin{array}{l}\text { Pre-treatment } \\
\text { period } \\
(\text { Days } 0-5)\end{array}$ & $13.43 \pm 3.18$ & $15.89 \pm 6.74$ & $18.42 \pm 7.91$ & $12.22 \pm 6.31$ \\
\hline $\begin{array}{l}\text { Treatment period } \\
\text { (Days 5-20) } \\
\text { Throughout }\end{array}$ & $73.88 \pm 7.16$ & $91.88 \pm 9.58$ & $79.28 \pm 15.37$ & $88.74 \pm 13.62$ \\
\hline $\begin{array}{l}\text { Gestation period } \\
\text { (Days } 0-20)\end{array}$ & $87.31 \pm 5.97$ & $107.77 \pm 13.29$ & $97.70 \pm 22.62$ & $100.95 \pm 18.36$ \\
\hline $\begin{array}{l}\text { Gravid Uterine } \\
\text { Weight }(\mathrm{g})^{\mathrm{c}}\end{array}$ & $62.76 \pm 3.16$ & $72.08 \pm 6.94$ & $61.51 \pm 11.09$ & $69.14 \pm 9.58$ \\
\hline $\begin{array}{l}\text { Corrected Mater- } \\
\text { nal Body weight } \\
\text { Gain }(\mathrm{g})^{\mathrm{c}}\end{array}$ & $11.12 \pm 9.30$ & $19.80 \pm 12.29$ & $17.77 \pm 15.19$ & $19.59 \pm 16.17$ \\
\hline $\begin{array}{l}\text { a: No. of pregnanci } \\
\text { b: No. of females w } \\
\text { c: Mean } \pm \text { SD }\end{array}$ & $\begin{array}{l}\text { No. of animal } \\
\text { live new bor }\end{array}$ & $\begin{array}{l}\text { with successful } \\
\text { /No. of pregnan }\end{array}$ & $\begin{array}{l}\text { opulation X } 10 \\
\text { ies X } 100\end{array}$ & \\
\hline
\end{tabular}

\subsection{Maternal parameters}

The total number of corpora lutea, the total number of implantations and the percentage of pre and post implantation loss were statistically unchanged in the 3 treated groups compared with the control group (Table 2).

Table 2: Maternal Parameters

\begin{tabular}{|c|c|c|c|c|}
\hline \multirow[b]{2}{*}{ End Point } & \multicolumn{4}{|c|}{ Treatment } \\
\hline & Control & $\begin{array}{l}50 \\
\mathrm{mg} / \mathrm{kg} / \mathrm{day}\end{array}$ & $\begin{array}{l}250 \\
\mathrm{mg} / \mathrm{kg} / \text { day }\end{array}$ & $\begin{array}{l}1000 \\
\mathrm{mg} / \mathrm{kg} / \mathrm{day}\end{array}$ \\
\hline $\begin{array}{l}\text { No. of Corpora } \\
\text { Lutea }^{a}\end{array}$ & $13.50 \pm 0.55$ & $15.83 \pm 1.72$ & $14.00 \pm 1.67$ & $14.50 \pm 2.35$ \\
\hline $\begin{array}{l}\text { No. of } \\
\text { Implantations }^{\mathrm{a}}\end{array}$ & $12.67 \pm 0.82$ & $14.50 \pm 1.05$ & $13.00 \pm 1.10$ & $12.83 \pm 1.94$ \\
\hline No. of resorptions $\mathrm{s}^{\mathrm{a}}$ & & & & \\
\hline 1. Early resorptions & $0.33 \pm 0.52$ & $0.33 \pm 0.82$ & $1.17 \pm 1.17$ & $0.00 \pm 0.00$ \\
\hline $\begin{array}{l}\text { 2. Late resorptions } \\
\text { \% Implantation Loss }\end{array}$ & $0.00 \pm 0.00$ & $0.17 \pm 0.41$ & $0.00 \pm 0.00$ & $0.00 \pm 0.00$ \\
\hline 1. Early & 6.17 & 8.42 & 7.14 & 11.49 \\
\hline $\begin{array}{l}\text { 2. Late } \\
\text { Dam with any } \\
\text { resorptions }\end{array}$ & 2.63 & 3.45 & 8.97 & 0.00 \\
\hline 1. Number & 2 & 2 & 4 & 0 \\
\hline $\begin{array}{l}\text { 2. } \% \\
\text { a: Mean } \pm \text { SD }\end{array}$ & 33.33 & 33.33 & 66.67 & 0.00 \\
\hline
\end{tabular}

\subsection{Litter parameters}

The total number of fetuses was significantly higher at 50 $\mathrm{mg} / \mathrm{kg} /$ day dose and the weight and length of male fetuses at 1000 $\mathrm{mg} / \mathrm{kg} /$ day was significantly higher (Table 3 ).

Table 3: Litter Parameters

\begin{tabular}{|c|c|c|c|c|}
\hline \multirow[b]{2}{*}{ End Point } & \multicolumn{4}{|c|}{ Treatment } \\
\hline & Control & $\begin{array}{l}50 \\
\mathrm{mg} / \mathrm{kg} / \text { day }\end{array}$ & $\begin{array}{l}250 \\
\mathrm{mg} / \mathrm{kg} / \text { day }\end{array}$ & $\begin{array}{l}1000 \\
\mathrm{mg} / \mathrm{kg} / \text { day }\end{array}$ \\
\hline $\begin{array}{l}\text { Total No. of } \\
\text { Fetuses }\end{array}$ & 74 & $84 *$ & 71 & 77 \\
\hline $\begin{array}{l}\text { Mean Litter } \\
\text { Size }\end{array}$ & 12.33 & 14.00 & 11.83 & 12.83 \\
\hline \multicolumn{5}{|l|}{$\begin{array}{l}\text { Fetal Body } \\
\text { weights }(\mathrm{g})^{\mathrm{a}}\end{array}$} \\
\hline 1. Males & $3.20 \pm 0.12$ & $3.25 \pm 0.17$ & $3.30 \pm 0.24$ & $3.69 \pm 0.14 *$ \\
\hline 2. Females & $3.10 \pm 0.17$ & $3.15 \pm 0.15$ & $3.27 \pm 0.35$ & $3.44 \pm 0.17$ \\
\hline \multicolumn{5}{|l|}{$\begin{array}{l}\text { Fetal length } \\
(\mathrm{mm})^{\mathrm{a}}\end{array}$} \\
\hline 1. Males & $33.88 \pm 0.83$ & $33.57 \pm 1.03$ & $33.97 \pm 1.53$ & $36.01 \pm 0.78^{*}$ \\
\hline 2. Females & $32.97 \pm 1.05$ & $32.97 \pm 1.38$ & $33.59 \pm 1.91$ & $34.39 \pm 0.41$ \\
\hline $\begin{array}{l}\text { Sex Ratio } \\
\text { (Male : Fe- } \\
\text { male) } \\
\text { a: Mean } \pm \text { SD } \\
\text { *: Significant }\end{array}$ & lifferent from & trol group, $\mathrm{P}$ & $1: 1.15$ & $1: 1.26$ \\
\hline
\end{tabular}




\subsection{Fetal morphological observations}

External examination of fetuses did not reveal any morphological abnormalities at any of the treated dose levels. The visceral/soft tissue evaluation also revealed no abnormalities in any of the organs. The skeletal system of fetus stained with alizarin red stain also did not show any major malformations (Table 4). The main findings were normal variations related to the ossification of some bone components like delayed/incomplete/poor ossification across the treated groups. In addition some minor anomalies like hypoplastic sternum, dumbbell/split centra, and rudimentary/accessory/extra ribs seen across the treated groups.

Table 4: Fetal Morphological Observations

\begin{tabular}{|c|c|c|c|c|}
\hline \multirow[b]{2}{*}{ End Point } & \multicolumn{4}{|c|}{ Treatment } \\
\hline & Control & $\begin{array}{l}50 \\
\mathrm{mg} / \mathrm{kg} / \text { day }\end{array}$ & $\begin{array}{l}250 \\
\mathrm{mg} / \mathrm{kg} / \text { day }\end{array}$ & $\begin{array}{l}1000 \\
\mathrm{mg} / \mathrm{kg} / \text { day }\end{array}$ \\
\hline No. of Litters & 6 & 6 & 6 & 6 \\
\hline Total No. of Fetuses & 74 & 84 & 71 & 77 \\
\hline $\begin{array}{l}\text { External } \\
\text { Examination }^{\mathrm{a}}\end{array}$ & $74(6)$ & $84(6)$ & $71(6)$ & $77(6)$ \\
\hline Abnormalities ${ }^{\mathrm{b}}$ & $00(0)$ & $00(0)$ & $00(0)$ & $00(0)$ \\
\hline $\begin{array}{l}\text { Soft tissue } \\
\text { alterations }^{\text {a }}\end{array}$ & $37(6)$ & $42(6)$ & $36(6)$ & $38(6)$ \\
\hline Abnormalities $^{\mathrm{b}}$ & $00(0)$ & $00(0)$ & $00(0)$ & $00(0)$ \\
\hline $\begin{array}{l}\text { Skeletal } \\
\text { Examination }^{\mathrm{a}}\end{array}$ & $37(6)$ & $42(6)$ & $35(6)$ & $39(6)$ \\
\hline $\begin{array}{l}\text { Hypoplastic Ster- } \\
\text { num No. } 5^{\text {b }}\end{array}$ & $00(0)$ & $02(2)$ & $02(2)$ & $02(2)$ \\
\hline Fetus (Litter) \% & $00(0)$ & $\begin{array}{l}4.76^{*} \\
\left(4.76^{*}\right)\end{array}$ & $\begin{array}{l}5.71^{*} \\
\left(5.16^{*}\right)\end{array}$ & $\begin{array}{l}5.13 * \\
(5.56 *)\end{array}$ \\
\hline $\begin{array}{l}\text { Accessory Rib No. } \\
14^{\mathrm{b}}\end{array}$ & $00(0)$ & $03(1)$ & $02(2)$ & $04 *(3)$ \\
\hline Fetus (Litter) \% & $00(0)$ & $\begin{array}{l}7.14^{*} \\
\left(6.25^{*}\right)\end{array}$ & $\begin{array}{l}5.71 * \\
(5.71 *)\end{array}$ & $\begin{array}{l}10.26^{*} \\
\left(11.11^{*}\right)\end{array}$ \\
\hline Extra Rib No. $14^{\mathrm{b}}$ & $00(0)$ & $00(0)$ & $00(0)$ & $02(1)$ \\
\hline Fetus (Litter) \% & $00(0)$ & $00(0)$ & $00(0)$ & $\begin{array}{l}5.13 * \\
(4.86 *)\end{array}$ \\
\hline $\begin{array}{l}\text { Rudimentary Rib } \\
\text { No. } 14^{\mathrm{b}}\end{array}$ & $11(6)$ & $22 *(6)$ & $15(5)$ & $25 *(6)$ \\
\hline Fetus (Litter) \% & $\begin{array}{l}29.73 \\
(30.63)\end{array}$ & $\begin{array}{l}52.38^{*} \\
(51.29)\end{array}$ & $\begin{array}{l}42.86 \\
(44.29)\end{array}$ & $\begin{array}{l}64.10 * \\
(63.59 *)\end{array}$ \\
\hline $\begin{array}{l}\text { Major } \\
\text { Malformations }{ }^{\mathrm{b}} \\
\text { a: Number of fetuses ( } \\
\text { b: Total Number of fe } \\
\text { *: Significantly differ }\end{array}$ & $\begin{array}{l}00(0) \\
\text { ters) } \\
\text { es (litte } \\
\text { t from c }\end{array}$ & $\begin{array}{l}\text { hibiting vari } \\
\text { group, } \mathrm{P} \leq 0\end{array}$ & $\mathrm{~s} / \mathrm{malformati}$ & $00(0)$ \\
\hline
\end{tabular}

Table 5: Biochemical Investigation

\begin{tabular}{|c|c|c|c|c|}
\hline \multirow[b]{2}{*}{ Parameter } & \multicolumn{4}{|c|}{ Treatment } \\
\hline & Control & $\begin{array}{l}50 \\
\mathrm{mg} / \mathrm{kg} / \text { day }\end{array}$ & $\begin{array}{l}250 \\
\mathrm{mg} / \mathrm{kg} / \text { day }\end{array}$ & $\begin{array}{l}1000 \\
\mathrm{mg} / \mathrm{kg} / \text { day }\end{array}$ \\
\hline $\begin{array}{l}\text { No. of GD } 20 \\
\text { dams } \rightarrow\end{array}$ & 6 & 6 & 6 & 6 \\
\hline $\begin{array}{l}\text { Glucose } \\
(\mathrm{mmol} / \mathrm{L})\end{array}$ & $5.23 \pm 0.32$ & $6.15 \pm 0.70$ & $5.48 \pm 0.93$ & $5.49 \pm 0.44$ \\
\hline $\begin{array}{l}\text { Total Cholesterol } \\
(\mathrm{mmol} / \mathrm{L})\end{array}$ & $1.76 \pm 0.65$ & $1.91 \pm 0.44$ & $2.55 \pm 0.76$ & $1.77 \pm 0.32$ \\
\hline $\begin{array}{l}\text { Total Protein } \\
(\mathrm{g} / \mathrm{L})\end{array}$ & $59.15 \pm 2.65$ & $84(6)$ & $71(6)$ & $77(6)$ \\
\hline AST (U/L) & $48.50 \pm 15.11$ & $61.67 \pm 8.91$ & $65.67 \pm 11.66$ & $56.17 \pm 2.32$ \\
\hline $\operatorname{ALT}(\mathrm{U} / \mathrm{L})$ & $63.17 \pm 9.47$ & $59.50 \pm 14.28$ & $58.33 \pm 20.91$ & $66.17 \pm 7.91$ \\
\hline $\operatorname{ALP}(\mathrm{U} / \mathrm{L})$ & $36.50 \pm 13.75$ & $67.83 \pm 46.81$ & $83.67 \pm 56.09$ & $50.17 \pm 15.73$ \\
\hline GGT (U/L) & $19.17 \pm 6.05$ & $19.00 \pm 3.79$ & $22.17 \pm 5.08$ & $18.83 \pm 6.21$ \\
\hline $\begin{array}{l}\text { Total Bilirubin } \\
(\mu \mathrm{mol} / \mathrm{L})\end{array}$ & $2.46 \pm 0.45$ & $2.91 \pm 0.43$ & $2.44 \pm 0.61$ & $2.53 \pm 0.57$ \\
\hline $\mathrm{BUN}(\mathrm{mmol} / \mathrm{L})$ & $5.51 \pm 0.32$ & $6.08 \pm 0.90$ & $6.87 \pm 1.85$ & $5.60 \pm 0.57$ \\
\hline $\begin{array}{l}\text { Creatinine } \\
(\mu \mathrm{mol} / \mathrm{L})\end{array}$ & $35.17 \pm 18.04$ & $45.17 \pm 5.38$ & $39.83 \pm 13.50$ & $46.83 \pm 7.52$ \\
\hline Albumin $(\mathrm{g} / \mathrm{L})$ & $38.68 \pm 1.60$ & $38.80 \pm 5.16$ & $37.93 \pm 7.09$ & $40.20 \pm 2.83$ \\
\hline $\begin{array}{l}\text { Calcium } \\
(\mathrm{mEq} / \mathrm{L})\end{array}$ & $2.20 \pm 0.27$ & $2.28 \pm 0.10$ & $2.28 \pm 0.20$ & $2.26 \pm 0.18$ \\
\hline Sodium $(\mathrm{mEq} / \mathrm{L})$ & $137.45 \pm 11.06$ & $145.55 \pm 11.68$ & $152.02 \pm 2.52$ & $147.17 \pm 4.00$ \\
\hline $\begin{array}{l}\text { Potassium } \\
(\mathrm{mEq} / \mathrm{L})\end{array}$ & $4.04 \pm 0.43$ & $4.57 \pm 0.65$ & $4.55 \pm 0.34 *$ & $4.39 \pm 0.31$ \\
\hline $\begin{array}{l}\text { Chloride } \\
(\mathrm{mEq} / \mathrm{L}) \\
\text { Values: Mean } \pm \text { SD } \\
\text { *: Significantly dif }\end{array}$ & $106.68 \pm 6.87$ & group, $\mathrm{P} \leq 0.05$ & $94.78 \pm 2.08^{*}$ & $100.38 \pm 3.76$ \\
\hline
\end{tabular}

\subsection{Biochemical investigation}

Biochemical investigation revealed that the markers of normal liver function [Aspartate Amino Transferase (AST), Alanine Aminotransferase (ALT), Alkaline Phosphatase (ALP), Gamma
Glutamyl Transpeptidase (GGT) and Total Bilirubin], markers of normal kidney function [Blood Urea Nitrogen (BUN), Creatinine, Albumin], electrolyte levels (sodium, potassium, chloride, calcium) and general metabolism (glucose, total cholesterol, total plasma protein) were all within the normal biological variation at all the treated levels when compared to the control (Table 5).

\section{Discussion}

Commercially saffron constitutes the dried red stigma of the flower. The pharmacologically important active constituents of saffron comprises the volatile agents (safranal), bitter principles (picrocrocin) and the colour component (crocetin and its glycosidic, crocin). Saffron is widely consumed by pregnant women mainly in the belief to increase fairness in newborn. It has been reported that saffron can stimulate uterine contractions in pregnant women leading to abortions. Also it is reported that high concentrations of crocetin, a carotenoid component giving a characteristic golden yellow orange colour to saffron was found to be teratogenic in frogs, Xenopus laevis. Due to lack of available data of teratogenic potential in a mammalian species, the objective of the present investigation was to determine the prenatal developmental toxicity of saffron to induce structural and / or other abnormalities in the fetus of a mammalian species (Wistar rats) when administered orally to pregnant rats during gestation days 5 through 19. Rat was selected as the model due to its common and wide use in teratogenicity testing. The oral route was selected to administer the test material as it simulated the exposure pattern of the human population.

The highest dose selected for the study was $1000 \mathrm{mg} / \mathrm{kg} / \mathrm{day}$ which are referred to as the limit dose by regulatory toxicity guidelines related to reproduction toxicity testing [Guidelines OECD 414 , ICH S5 (R2)]. $1 / 4^{\text {th }}$ the highest dose $(250 \mathrm{mg} / \mathrm{kg} /$ day $)$ was selected as the mid dose and $1 / 5^{\text {th }}$ the mid dose $(50$ $\mathrm{mg} / \mathrm{kg} / \mathrm{day}$ ) was selected as the low dose. The control rats received Milli-Q water, which was used to suspend the saffron at low, mid and high doses.

Treatment with saffron up to the highest dose of $1000 \mathrm{mg} / \mathrm{kg} /$ day did not elicit any adverse clinical signs, effects on gestation body weight or food intake. The maternal parameters comprising of gravid uterine weight, corpora lutea and implantation counts, early and late resorptions, pre and post implantation loss and dams with any resorptions were all comparable to the control at the tested doses. The litter parameters comprising of the number of fetuses were incidentally higher at $50 \mathrm{mg} / \mathrm{kg} /$ day dose and the weight and length of the male fetuses were significantly higher at 1000 $\mathrm{mg} / \mathrm{kg} /$ day dose. This increase observed in the fetal body weight by around $13 \%$ and length by around 5\% without any effect on maternal body weight gain and gravid uterine weight is considered non-adverse

Fetal external and visceral examination revealed no signs of teratogenicity or developmental toxicity up to the highest dose of $1000 \mathrm{mg} / \mathrm{kg} /$ day. Skeletal examination also revealed no malformations except for normal variations related to the ossification of some bone components like delayed/incomplete/poor ossification across the treated groups. In addition some minor anomalies like hypoplastic sternum, dumbbell/split centra, and rudimentary/accessory/extra ribs were seen across the treated groups. These normal variations and minor anomalies are commonly seen in a fetus from day 20 gestation dam.

Biochemical investigations carried out from the blood collected at caesarean section to detect any adverse biochemical effects indicative of abnormal liver and kidney functioning, electrolyte imbalances or general metabolism revealed that all the parameters were within the normal biological variation up to the highest dose of $1000 \mathrm{mg} / \mathrm{kg} /$ day dose when compared to the control. 


\section{Conclusion}

The study indicated that saffron did not induce any maternal toxicity and fetal developmental toxicity in Wistar rats when saffron was administered orally daily by gavage during gestation days 5 to 19 up to the highest tested dose of $1000 \mathrm{mg} / \mathrm{kg} /$ day. Hence saffron is considered to have no teratogenic potential up to the highest tested dose of $1000 \mathrm{mg} / \mathrm{kg} / \mathrm{day}$ under the test conditions.

\section{Acknowledgements}

The authors gratefully acknowledge the Management of Advinus Therapeutics Limited for the support given for the research by providing all the necessary permission, infrastructure, and animals for the conduct of the research. In addition would also like to acknowledge the Saffron Industry in particular Mr. Masoodi Tajamul for providing quality saffron at reasonable price.

\section{References}

[1] Vijaya Bhargava K (2011) Medicinal Uses and Pharmacological Properties of Crocus sativus linn (Saffron). International Journal of Pharmacy and Pharmaceutical Sciences 3 (3), 22 - 26.

[2] Hossein HosseinZadeh, Saied Sadeghi Shakib, Abbas Khadem Sameni \& Elahe Taghiabad (2013) Acute and Subacute Toxicity of Safranal, a constituent of saffron, in mice and rats. Iranian Journal of Pharmaceutical Research 12(1), 93 - 99.

[3] Martin G, Goh E and Neff AW (2002) Evaluation of the Developmental Toxicity of Crocetin on Xenopus. Food and Chemical Toxicology 40, 959 - 964. http://dx.doi.org/10.1016/S0278-6915 (02)00040-6.

[4] Staples RE (1974) Detection of Visceral Alterations in Mammalian Fetuses. Teratology 9(3), A37 - A38.

[5] Staples RE and Schnell VL (1964) Refinements in Rapid Clearing Technic in the $\mathrm{KOH}-$ Alizarin Red S Method for Fetal Bone. Stain Technology 39, $61-63$.

[6] Rochelle W Tyl and Melissa C Marr (2006) Developmental Toxicity Testing - Methodology. Developmental and Reproductive Toxicology (Ronald D. Hood ed.), CRC Press, Taylor and Francis Group pp. 201 -256 .

[7] Organisation for Economic Co-operation and Development (OECD) Guideline for the Testing of Chemical, No. 414, Prenatal Developmental Toxicity study, January 22, 2001.

[8] International Conference on Harmonization (ICH), S5 (R2) Guideline for Industry - Detection of Toxicity to Reproduction for Medicinal products, Study for effects on Embryo-Fetal Development, 4.1.3, November 2005 